\title{
Thallus anatomy of Canoparmelia texana (Parmeliaceae, lichenized Ascomycota)
}

\author{
Suzana Bissacot Barbosa ${ }^{1,3}$, Silvia Rodrigues Machado ${ }^{1}$ \& Marcelo Pinto Marcelli $^{2}$ \\ ${ }^{1}$ Departamento de Botânica, Instituto de Biociências, Universidade Estadual Paulista - UNESP, \\ CP 510, CEP 18618-000, Botucatu, SP, Brasil \\ ${ }^{2}$ Seção de Micologia e Liquenologia, Instituto de Botânica, \\ CP 3005, CEP 01061-970, São Paulo, SP, Brasil \\ ${ }^{3}$ Corresponding author: Suzana Bissacot Barbosa, e-mail: suzibissacot@hotmail.com
}

BARBOSA, S.B., MACHADO, S.R. \& MARCELLI, M.P. Thallus anatomy of Canoparmelia texana (Parmeliaceae, lichenized Ascomycota). Biota Neotrop. 10(3): http://www.biotaneotropica.org.br/v10n3/en/ abstract?article+bn02810032010.

\begin{abstract}
Conventional techniques for structural studies under light microscope and scanning electron microscope were employed to describe the histology of thallus in Canoparmelia texana, a lichen with wide distribution in open environments and fairly common in the cerrados and urban areas of Brazil. This study describes a new type of cortical organization for the family Parmeliaceae, in C. texana the upper cortex is lacunar, showing a large quantity of small intercellular spaces or lacunae. The anatomical features including medulla thickness, hyphal orientation pattern, rhizines thickness and crystals inclusions have an important adaptive role for the success of C. texana in Brazilian cerrado, a savanna-like ecosystem.

Keywords: anatomy, crystals, lacunar upper cortex, Parmeliaceae.
\end{abstract}

BARBOSA, S.B., MACHADO, S.R. \& MARCELLI, M.P. Anatomia do talo de Canoparmelia texana (Parmeliaceae, Ascomycota liquenizados). Biota Neotrop. 10(3): http://www.biotaneotropica.org.br/v10n3/pt/ abstract?article+bn02810032010.

Resumo: Técnicas convencionais para estudos anatômicos em microscopia de luz e microscopia eletrônica de varredura foram utilizadas para descrever a histologia do talo de Canoparmelia texana, um líquen com ampla distribuição em ambientes abertos e bastante comum nos cerrados e em áreas urbanas no Brasil. Este estudo descreve um novo tipo de organização cortical para Parmeliaceae. Em C. texana o córtex superior é lacunar mostrando uma grande quantidade de pequenos espaços intracelulares. As características anatômicas incluindo a espessura da medula, o padrão de orientação das hifas, espessura das rizinas e inclusões de cristais aparentemente possuem um importante papel adaptativo para o sucesso de $C$. texana nos cerrados brasileiros.

Palavras-chave: anatomia, cristais, córtex superior lacunoso, Parmeliaceae. 


\section{Introduction}

Parmeliaceae represents the largest family within Lecanorales with more than 2000 species in about 90 genera and includes taxa with different growth forms. Crespo et al. (2007) have tested morphology-based grouping using DNA sequence data and concluded that this family is strongly support as monophyletic and six well-supported main clades can be distinguished within Parmeliaceae. The parmelioid group is the largest clade within the family, and is characterized by foliose thallus, rhizines on the lower surface, laminal apothecia, Lecanora-type asci and simple hyaline ascospores (Crespo et al. 2001). However, the current generic concepts in this are in need of revision because polyphyly of some genera, such as Canoparmelia, has been detected (Crespo et al. 2007).

Canoparmelia texana (Tuck.) Elix \& Hale is a foliose lichen with wide distribution in open environments and fairly common in the cerrados and urban areas of Brazil (Nagaoka \& Marcelli 1989). This species is found mainly on bark and has been studied because of its potential as bioindicator of air pollution (Saiki et al. 2003). It is characterized by the presence of soredia formed in rounded soralia, conspicuous maculae and the presence of atranorin in the upper cotex and divaricatic acid in the medulla (Elix et al. 1986).

The aim of the present investigation is to make a precise study of the anatomy of the Canoparmelia texana with emphasis on the upper cortex anatomy. This work is the continuity of a project started in 2003 as part of the master's dissertation of Barbosa (2004) which aimed to the description of a protocol for anatomical studies in species of Parmeliaceae (Barbosa et al. 2009a).

\section{Material and Methods}

Thalli of Canoparmelia texana (Tuck.) Elix \& Hale were collected in February to April 2004 from the bark of different trees occurring in a cerrado community located in the Municipalities of Pratânia (22 48' 50.2' ' S and 48 44'35.8' W) and Botucatu (22 48' 55.5' S and $48^{\circ} 31^{\prime} 26.1$ ' W), both in São Paulo State, Brazil.

Longitudinal and transversal sections of $0.5 \times 1.0 \mathrm{~cm}$ long were taken from the median region of three different thalli and were processed for light and scanning electron microscopy analysis. Three blocks were prepared for each sampled thallus and at least four slides of each block were obtained.

For light microscope analyses, the material was prepared according to the protocol established by Barbosa et al. (2009a) for Parmeliaceae. Samples were fixed in formalin-acetic acid-alcohol 50 (FAA 50) for 48 hours (Johansen 1940), dehydrated in a graded ethanol series, and embedded in plastic resin (Leica Historesin). Serial sections (2-5 $\mu \mathrm{m}$ thick) were sectioned in both transverse and longitudinal orientations with a steel knife on a semi-automatic rotary microtome and stained with toluidine blue $\mathrm{O} 0.05 \%, \mathrm{pH} 4.7$ (O'Brien et al. 1964). Permanent slides were mounted in synthetic resin and were photographed under a Zeiss photomicroscope, with and without polarizer filter, using Pro Image 100 film.

For scanning electron microscopy analyses, air-dried samples were attached to aluminum stubs and coated with gold $(10 \mathrm{~nm})$. The samples were then examined under a FEI Quanta scanning electron microscopy at $20 \mathrm{kV}$.

Description of the species follows the protocol developed by the Group for Lichenological Studies of Instituto de Botânica, in São Paulo city, adapted for anatomical data by Barbosa (2004).

\section{Results}

\section{Anatomical description}

Canoparmelia texana (Tuck.) Elix \& Hale (Mycotaxon 27(4): 279. 1986). (Figures 1a-f, 2a-c)

Epicortex 0.75-2.00 $\mu \mathrm{m}$ high, pored (Figures 1b, 1c). Upper cortex lacunar, formed by the juxtaposition of apical cell(s) of hyphae that protrude from the medulla 1-3 cells height (5.00-20.00 $\mu \mathrm{m})$, with small slightly elongated cells of thick walls, (5.00-) 7.50-10.00 × 2.50-3.75 (-5.00) $\mu \mathrm{m}$, with small intercellular spaces frequently $2.50-10.00 \mu \mathrm{m}$ diam. (Figure $1 \mathrm{c}$ ), and with a conspicuous continuous layer of birefringent crystals. algal layer 1-3 cells height (7.50-32.50 $\mu \mathrm{m})$, with round cells (5.00-) 7.50-10.00 $\mu \mathrm{m}$ diam., thick walls and heterogeneous cell content; hyphae cells (5.00-) 7.50-10.00 × $2.50(-7.50) \mu \mathrm{m}$ (Figure 1c). Medulla 100.00-150.00 $\mu \mathrm{m}$ height, hyphae in a predominantly horizontal arrangement, transversal horizontal hyphae mainly in the medulla lower part, with elongated cells (10.00-) $17.50 \times 1.25$ $(-2.50) \mu \mathrm{m}$ (Figures 1c, d). Crystals in median part of the medulla yellowish, resembling small grains dispersed among the hyphae, many of them morphologically resembling a string of beads around the hyphae. (Figures 1d, 1f). Soralia 120.00-150.00 $\mu \mathrm{m}$ diam. (Figures 1d, 2a), roundish soredia 2.50-7.50 $\mu \mathrm{m}$ diam., with 1-6 algal cells, formed from the medullary hyphae, sometimes showing remains of upper cortex, or developed into totally corticate granules. (Figures $2 \mathrm{a}, \mathrm{b}$ ). Isidia absent. Lower cortex prosoplectenchymatous $1-3$ cells height $(5.00-25.00 \mu \mathrm{m})$, with small round cells (2.50-) 5.00-12.50 $\mu$ m diameter, formed from the juxtaposition of longitudinal horizontal hyphae (Figure 2c); rhizines simple, sometimes with forked apices, corticated only on the base, formed from cortical tissue and medullary hyphae, constituted of a bundle of agglutinated parallel hyphae coated with a layer of prosoplectenchymatic cortex only on the base, $10.00-30.00 \mu \mathrm{m}$ diameter, equivalent to $10-20$ parallel hyphae of 2.50-3.75 $\mu \mathrm{m}$ diam. each one (Figure $2 \mathrm{c}$ ).

\section{Discussion}

Studying the thallus anatomy of Canoparmelia texana we found a new type of cortical organization for Parmeliaceae. In this species the upper cortex is lacunar, showing a large quantity of small intercellular spaces or lacunae. The cortical cells are more or less vertically arranged and present elongate lumina in vertical sections, agreeing with Hale (1981) and Elix (1993) who consider this type of cortex as a palisade plectenchyma. However none of them observed the cavities shown here.

As pointed by Divakar et al. (2007) and Barbosa et al. (2009b) for anatomical investigations of upper cortex is essential to make sections in both perpendicular (transverse) and parallel (longitudinal) to the growth direction of the lobe. With this kind of analysis we could distinguish the type of upper cortex found in C. texana from the type of Parmotrema cortex visualized by Hale (1981), Barbosa et al. (2009b) and Barbosa \& Marcelli (2010).

According to Barbosa et al. (2009b) and Hale (1981) in $P$. tinctorum, the upper cortex is very thick and hyphal cells are agglutinated, but there are small interstices which may act together with epicortical pores in gas exchanges; the cortex high thickness can act as a barrier to water diffusion, lengthening the thallus saturation time, as observed by Hale (1981) in other Parmeliaceae species. The cortex of Parmotrema tinctorum showed a thick-walled palisade prosoplectenchymatous tissue appearing similar in the two kinds of sections (transversal and longitudinal), formed by the juxtaposition of 
Thallus anatomy of Canoparmelia texana
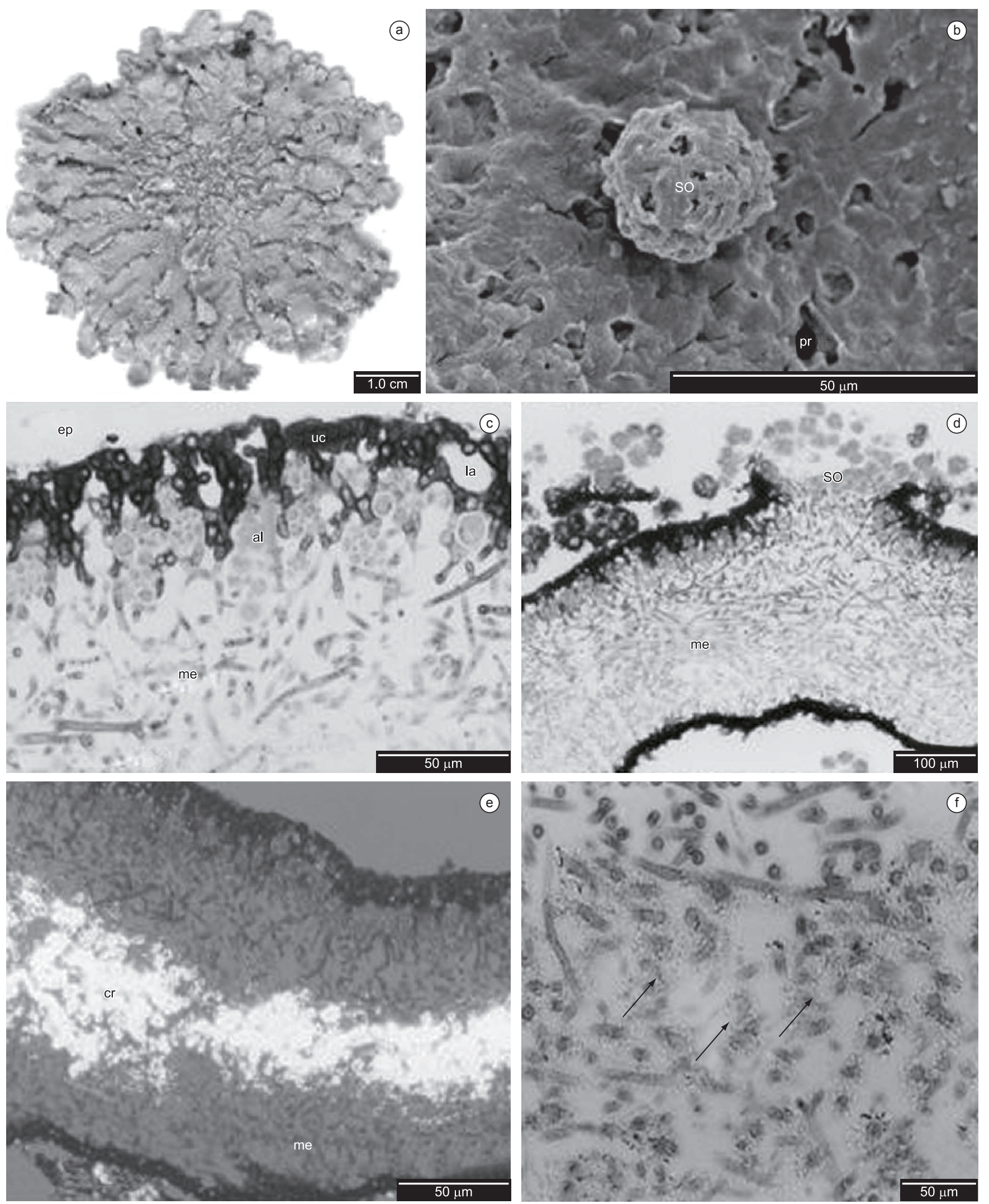

Figure 1. a) General view of Canoparmelia texana; b) Scanning electron microscopy - showing epicortex (ep), pores (pr) and soredia (so); c-f) Light microscopy - transversal sections; c) Detail of the upper cortex (uc), showing epicortex (ep), lacuna (la) and algal layer (al); d) Transversal section showing soredia (so) and medulla (me); e) Detail of medulla (me) with crystals of lichen acids (arrow) under polarized light; f) Detail of crystals (arrows) in the medulla under normal light. 


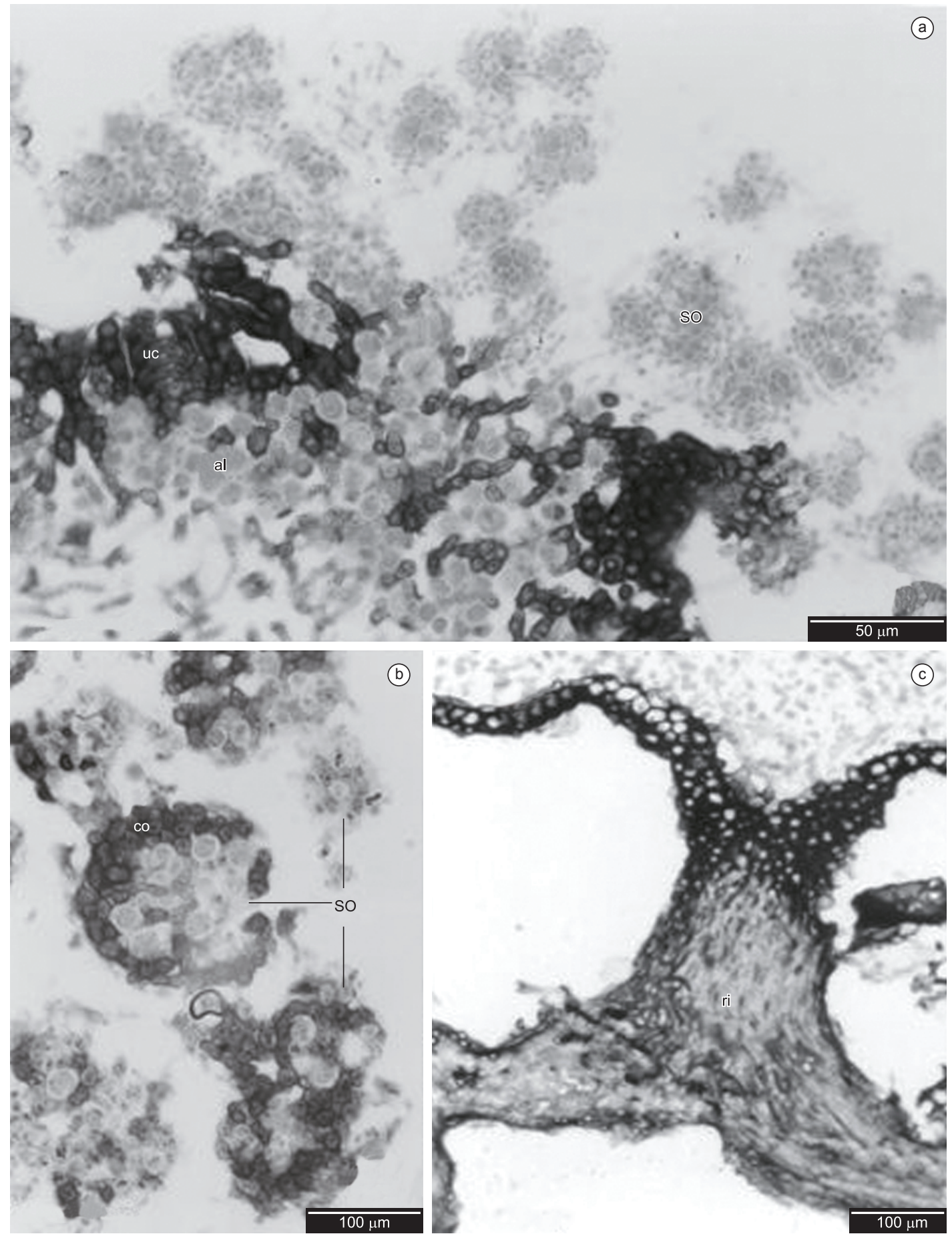

Figure 2. Light microscopy - transversal sections. a) Transversal section showing soralia with soredia (so), upper cortex (uc) and algal layer (al); b) Detail of granules showing the presence of cortex (co); c) Detail of lower cortex (lc) and rhizine (ri).

apical cells of hyphae that protrude from the medulla and irregularly branched through the layer. In $C$. texana the presence of the regular intercellular spaces makes the upper cortex with a lacunar appearance. The presence of these lacunae may be associated with the thallus water uptake and $\mathrm{CO}_{2}$ diffusion capacity and perhaps act together with the pored epicortex, as considered by Hale (1981) for other Parmeliaceae species.

The several different lichen morphologies occurring in nature are associated with the requirements to expose sufficient area with photobionts to light for photosynthesis (Hale 1983, Crespo et al.
2007). Anatomically, many lichens have a structure that remember the plant leaves, interpreted as an evolutionary convergence of totally different leafy organs in direction to photosynthesis efficiency (Sanders 2001): like an epidermis, the upper cortex of lichen protects the photosynthetic cells bellow, slowing evaporation and filtering harmful or excessive radiation with the assistance of pigments and secondary substances (Hale 1983, Rikkinen 1995).

A large quantity of morphological structures and secondary metabolites are believed to have an important adaptive role for the success of lichens (Sanders 2001, Blanco et al. 2006, Barbosa 
et al. 2009b). Morphological traits include cortical layers composed of fungal hyphae that protect photosynthetic partners from high insolation (Jahns 1973, Blanco et al. 2006) and pores of different kinds and sizes that facilitate gas exchange through the cortex (Hale 1981).

Foliose lichens develop a variety of taxonomically and functionally important complex tissues in the upper and lower cortices (Ozenda 1963, Hawksworth et al. 1995, Divakar et al. 2006, Barbosa et al. 2009b). The structure of the upper cortex is used in family delimitation, e.g. Ramalinaceae (Bowler 1981), as well to distinguish genera, such as Anaptychia and Physconia (Moberg 1977), Bryocaulon, Coelocaulon and Cornicularia (Kärnefelt 1986), and Parmelia from Punctelia (Modenesi 1987).

Nevertheless, a molecular study made by Divakar et al. (2006) in order to evaluate the morphological characters used to circumscribe parmelioid genera, such as the cortical anatomy, demonstrated only minor value in identifying monophyletic groups in Hypotrachyna clade of Parmeliaceae, concluding the necessity of more morphological and anatomical analysis in this group.

The definitions found in literature for different types of lichens tissues are not congruent (Ozenda 1963, Hale 1976, Elix 1993, Hawksworth et al. 1995) showing the necessity for detailed anatomical studies as this study has shown. In this particular point, Ozenda (1963) stated that both upper and lower cortices are prosoplectenchymatous with thin-walled cells in Parmeliaceae, while Hale (1976) asserted that cortical layers in Parmeliaceae are a pachydermatous paraplectenchyma. Elix (1993) considered that the genera of the family would be characterized by palisadeplectenchymatous upper cortex, including the Canoparmelia species. Nevertheless, the data obtained here evidently showed that the upper and lower cortices in Canoparmelia texana have different patterns of organization. The upper cortex is lacunar while the lower cortex is prosoplectenchymatous formed by the juxtaposition of longitudinal horizontal hyphae with small round cells.

The birefringent crystals observed on upper cortex in C. texana are possibly formed by atranorin, a common depside that appears in many lichens, and like other lichen compounds, is fluorescent (Hale 1961). It may be helpful as accessory light absorbs in lichen thallus, it may increase the ability of the lichen alga to use light of smaller wavelengths and thus permit maximum utilization of low light intensities (Rao \& Lê Blanc 1965).

The medulla, the thickest layer in C. texana, is made of hyphal filaments formed by elongated cells. Usually, there are colored substances deposited among or on the hyphal cell walls in lichenized fungi (Peveling 1973, Hale 1976, Barbosa et al. 2009a, b). In C. texana, the crystals of lichen acids occur mostly on median region of the medulla, and probably these crystals are composed by divaricatic acid; it is this depside that also absorbs solar radiations and act mostly as growth regulator and against herbivores (Bjerke et al. 2002).

The rhizine constitution is controversial in Parmeliaceae (Barbosa et al. 2009b). For several authors rhizines are generally composed of more or less parallel arrangement of aligned and agglutinated hyphae, constituting a direct prolongation of the lower cortical tissue, with no participation of the medulla (Ozenda, 1963; Jahns, 1973). Only Beltman (1978) and Barbosa et al. (2009a, b) considers Parmeliaceae rhizines formed of both cortical tissue and medullary hyphae, as observed in Canoparmelia texana, showing that the structure of rhizines can be complex and probably associated with the size thallus and their adherence to substrate. Like Parmelinopsis minarum, C. texana is highly adhered to the substrate and there is no need of a supporting tissue.
In summary, the anatomical features and crystals inclusions probably have an important adaptive role for the success of C. texana in Brazilian cerrado, a savanna-like ecosystem, which has a large structural and physiognomical heterogeneity (Coutinho 1978). This environment is characterized by distinct wet and dry seasons with very few rainfall events and a long period with high precipitations. Evaporative demand is substantially higher during the dry season because of lower ambient relative humidity. The combination of higher evaporative demand and low precipitation during the dry season makes the cerrado a potentially stressful environment (Bucci et al. 2008). So, these features, combined with the anatomical traces founded in C. texana, are essentials for this lichen success since lichens in general require alternating periods of wetting and drying of the thallus (Pearson 1970).

\section{Acknowledgements}

We thank FAPESP- BIOTA Program (process $n^{\circ}$ 00/12469-3) for financial support to this study; CAPES/PNPD (project n 02749/09-2) for the fellowship to S.B. Barbosa; CNPq (Research grant to M.P. Marcelli and S.R. Machado) and the technical team of the Institute of Biosciences' Electron Microscopy Center, UNESP Botucatu, SP, Brazil, for his helpful technical advice.

\section{References}

BARBOSA, S.B. \& MARCELLI, M.P. 2010. Cortical diversity in three species groups of Parmotrema sensu lato (Parmeliaceae, lichenized Ascomycota). Micron 41:861-869.

BARBOSA, S.B. 2004. Estudos anatômicos em quatro espécies de Parmeliaceae (Ascomycota liquenizados). Master Thesis in Biological Sciences, São Paulo State University - UNESP, Botucatu, São Paulo State, Brazil.

BARBOSA, S.B., MACHADO, S.R. \& MARCELLI, M.P. 2009b. Thallus structure and isidium development in two Parmeliaceae species (lichenized Ascomycota). Micron 40:536-542.

BARBOSA, S.B., MARCELLI, M.P. \& MACHADO, S.R. 2009a. Evaluation of different protocols for anatomical studies in Parmeliaceae (lichenized Ascomycota). Micron 40:218-225.

BELTMAN, H.A. 1978. Vegetative structuren der Parmeliaceae und ihre entwicklung. Bibliot. Lichenol. 2:1-193.

BJERKE, J.W., LERFALL, K. \& ELVEBAKK, A. 2002. Effects of ultraviolet radiation and PAR on the content of usnic and divaricatic acids in two arctic-alpine lichens. Photochem. Photobiol. Sci. 1:678-685.

BLANCO, O., CRESPO, A., REE, R.H. \& LUMBSCH, H.T. 2006. Major clades of parmelioid lichens (Parmeliaceae, Ascomycota) and the evolution of their morphological and chemical diversity. Mol. Phyl. Evol. 39:52-69.

BOWLER, P.A. 1981. Cortical diversity in the Ramalinaceae. Can. J. Bot. 59:425-557.

BUCCI, S.J., SCHOLZ, F.G., GOLDSTEIN, G., MEINZER, F.C., FRANCO, A.C., ZHANG, Y. \& HAO, G.Y. 2008. Water relations and hydraulic architecture in Cerrado trees: adjustments to seasonal changes in water availability and evaporative demand. Braz. J. Plant Physiol. 20:233-245.

COUTINHO, L.M. 1978. O conceito de cerrado. Rev. Bras. Bot. 1:17-23.

CRESPO, A., BLANCO, O. \& HAWKSWORTH, D.L. 2001. The potencial of mitochondrial DNA for establishing phylogeny and stablishing generic concepts in the parmelioid lichens. Taxon 50:807-819.

CRESPO, A., LUMBSH, T., MATTSSON, J.E., BLANCO, O., DIVAKAR, P.K., ARTICUS, K., WIKLUND, E., BAWINGAN, P.A. \& WEDIN, M. 2007. Testing morphology-based hypotheses of phylogenetic relationships in Parmeliaceae (Ascomycota) using three ribosomal markers and nuclear RPB1 gene. Mol. Phyl. Evol.. 44:812-824. 
DIVAKAR, P.K., AMO DE PAZ, G., DEL PRADO, R., ESSLINGER, T.L. \& CRESPO, A. 2007. Upper cortex anatomy corroborates phylogenetic hypothesis in species of Physconia (Ascomycota, Lecanoromycetes). Mycol. Res. 111:1311-1320.

DIVAKAR, P.K., CRESPO, A., BLANCO, O. \& LUMBSCH, T.L. 2006. Plylogenetic significance of morphological characters in the tropical Hypotrachyna clade of parmelioid lichens (Parmeliaceae, Ascomycota). Mol. Phyl. Evol. 40:448-458.

ELIX, J.A. 1993. Progress in the generic delimitation of Parmelia sensu lato lichens (Ascomycotina: Parmeliaceae) and a synoptic key to the Parmeliaceae. The Bryologist 96:359-383.

ELIX, J.A., JOHNSTON, J. \& VERDON, D. 1986. Canoparmelia, Paraparmelia and Relicinopsis, three new genera in the Parmeliaceae (Lichenized Ascomycotina). Mycotaxon 27:271-282.

HALE, M.E. 1961. Lichen handbook. Washington, D.C.

HALE, M.E. 1976. Lichen structure viewed with the scanning electron microscope. In Lichenology: Progress and Problems. (D.H. Brown, D.L. Hawksworth \& B.H. Bailey, Ed.). Academic Press, London, p.1-15.

HALE, M.E. 1981. Pseudocyphellae and pored epicortex in the Parmeliaceae: their delimitation and evolutionary significance. Lichenologist 13:1-10.

HALE, M.E. 1983. The Biology of Lichens. Edward Arnold, Baltimore.

HAWKSWORTH, D.L., KIRK, P.M., SUTTON, B.C. \& PEGLER, D.N. 1995. Dictionary of the Fungi. $8^{\text {th }}$ ed. International Mycological Institute, CAB International.

JAHNS, H.M. 1973. Anatomy, morphology and development. In The Lichens (V. Ahmadjian \& M.E. Hale, Ed.). Academic Press, New York, p.3-58.

JOHANSEN, D.A. 1940. Plant microtechnique. Mc Graw-Hill, New York.

KÄRNEFELT, I. 1986. The genera Bryocaulon, Coelocaulon and Cornicularia and formely associated taxa. Opera Bot. 86:1-90.
MOBERG, R. 1977. The lichen genus Physcia and allied genera in Fennoscandia. Symb. Bot. Upsal. 22:1-108.

MODENESI, P. 1987. Histochemistry and generic delimitation in Parmelia and Punctelia. Nova Hedwigia. 45:423-431.

NAGAOKA, L.Y. \& MARCELLI, M.P. 1989. Liquens da Área de Reserva do Parque Estadual das Fontes do Ipiranga. Acta Bot. Bras. 3(2):95-98. Suplemento.

O'BRIEN, T.P., FEDER, N. \& McCULLY, M.E. 1964. Polychromatic staining of plant cell walls by toluidine blue O. Protoplasma 63:443-478.

OZENDA, P. 1963. Lichens: Traité d'anatomie végétale. Gebrüder Borntraeger, Nikolassee, Berlin.

PEARSON, L.C. 1970. Varying environmental factors in order to grow intact lichens under laboratory conditions. Am. J. Bot. 57:659-664.

PEVELING, E. 1973. Fine structure. In The Lichens. (V. Ahmadjian \& M.E. Hale, Ed.). Academic Press, New York, p.147-182.

RAO, D.N. \& LEBLANC, B.F. 1965. A possible role of atranorin in the lichen thallus. The Bryologist 68:284- 289.

RIKKINEN, J. 1995. What's behind the pretty colours? A Study on the photobiology of lichens. Bryobrothera 4:1-239.

SAIKI, M., HORIMOTO, L.K., VASCONCELLOS, M.B.A. \& MARCELLI, M.P. 2003. Substrate influence on elemental compsosition of Canoparmelia texana lichenized fungi. IAEA-TECDOC 1338: 271-277.

SANDERS, W.B. 2001. Lichens: the Interface between Mycology and Plant Morphology. Bioscience 51:1025-1035.

Received 14/01/2010

Revised 11/08/2010

Accepted 14/08/2010 